\title{
BANTEN DAN ANGKA KEKERASAN TERHADAP PEREMPUAN PERSFEKTIF AGAMA ISLAM
}

\author{
Muh Turizal Husein \\ (Fakultas Agama Islam Universitas Muhammadiyah Tangerang) \\ abiturizal68@gmail.com \\ Zainal Arif \\ zarifpambon@gmail.com \\ (Fakultas Agama Islam Universitas Muhammadiyah Tangerang)
}

\begin{abstract}
Abstrak
Penelitian ini bertujuan untuk mengetahui seberapa besar perhatian pemerintah dalam pemenuhan hak-hak warga negara yang termaktub dalam UUD 1945 dan Pancasila. Dibutuhkan suatu kebijakan yang dapat meningkatkan hak atas kepastian hukum, pengakuan, jaminan, dan keadilan bagi masyarakat terutama bagi kaum perempuan. Jenis penelitian ini adalah penelitian studi kasus (case study) dengan menggunakan metode penelitian kualitatif. Penelitian ini melakukan studi kasus di Provinsi Banten untuk mempelajari secara intensif mengenai latar belakang masalah kekerasan terhadap kaum perempuan dalam persfektif Pendidikan Islam dan sekaligus mencarikan solusi mengatasinya. Penetapan informan sebagai sumber data menggunakan teknik purposive sampling dan pengumpulan data menggunakan teknik observasi dan dokumentasi. Hasil penelitian menunjukkan bahwa (1) Kekerasan seksual terhadap perempuan di Indonesia terus meningkat dan semakin kompleks. Dengan jumlah korban setiap tahun mencapai ratusan ribu orang. Data tersebut, bila dikaitkan dalam kurun waktu 12 tahun, meningkat sebanyak 792\% atau hampir 800\% (2) Untuk Provinsi Banten permohonan perlindungan korban berbagai kasus yang dimintakan pada LPSK masih tergolong kecil, seperti data pada tahun 2018 hanya 83 permohonan.dalam pesfektif Agama Islam memberikan perlindungan terhadap perempuan dalam banyak aspek. Dengan demikian, sangat tragis jika teks-teks normative dalam Islam dipahami sebagaimana adanya atau secara tekstual semata, sehingga agama Islam memiliki kesan tidak manusiawi dan tidak berpihak terhadap kaum perempuan.
\end{abstract}

\section{Kata kunci: Kekerasan, Persfektif, LPSK}

\begin{abstract}
This study aims to determine how much government attention is in fulfilling the rights of citizens as stipulated in the 1945 Constitution and Pancasila. A policy is needed that can increase the right to legal certainty, recognition, guarantee and justice for the community, especially for women. This type of research is a case study research using qualitative research methods. This research conducted a case study in Banten Province to study intensively about the background of the problem of violence against women in the perspective of Islamic education and at the same time find a solution to overcome it. Determination of informants as data sources using purposive sampling technique and data collection using observation and documentation techniques. The results showed that (1) Sexual violence against women in Indonesia continues to increase and is increasingly complex. With the number of victims every year reaching hundreds of thousands of people. This data, if linked over a period of 12 years, increased by $792 \%$ or almost $800 \%$ (2) For Banten Province, requests for protection of victims of various cases which were requested from the LPSK were
\end{abstract}


still relatively small, such as data in 2018 only 83 applications in the religious perspective Islam provides protection for women in many aspects. Thus, it is tragic if normative texts in Islam are understood as they are or only textually, so that the Islamic religion has the impression of being inhuman and not taking sides with women.

\section{Keywords: Violence, Perspective, LPSK}

\section{A. Pendahuluan}

Sebagai Provinsi yang terletak di wilayah paling barat Pulau Jawa dan wilayah penyangga Ibu Kota Negara, telah memposisikan Provinsi Banten sebagai pintu gerbang Pulau Jawa dan Sumatera. Sejak berdiri pada tahun 2000 yang lalu, telah banyak pembangunan yang telah dilaksanakan. Namun di tengah tengah kemajuan yang sedang digagas oleh pemerintah daerah, Banten sampai saat ini masih menghadapi sejumlah tantangan dan begitu lekat dengan ketertinggalan. Diantaranya adalah korupsi, kemiskinan, pengangguran, sekolah, dan infrastruktur rusak serta yang lagi marak selama 3 (tiga) tahun terakhir, hangat diperbincangkan dan menjadi isu kontroversial adalah kekerasan terhadap perempuan.

Merujuk pemenuhan hak-hak warga negara, dalam UUD 1945 dan Pancasila, maka rakyat berhak atas keadilan, rasa aman, dan kesejahteraan sebagaimana termuat dalam UUD 1945. Termuat dalam hak atas kepastian hukum, pengakuan, jaminan, dan keadilan, Pasal 28 huruf (D), Pasal 27 ayat (1), dan hak bebas dari ancaman, diskriminasi, dan kekerasan yakni Pasal 28. Serta hak bebas dari ancaman, diskriminasi, dan kekerasan dalam Pasal 28 huruf (G) serta hak untuk mendapat kemudahan dan perlakuan khusus untuk memperoleh kesempatan dan manfaat yang sama guna mencapai persamaan dan keadilan, Pasal 28 huruf (H) ayat (2). Sedangkan dalam dalam pancasila termuat dalam sila ke tiga (persatuan Indonesia), keempat (kerakyatan yang dipimpin oleh hikmah kebijaksanaan dalam permusyawaratan/ perwakilan, dan kelima (keadilan sosila bagi seluruh rakyat Indonesia) ${ }^{1}$.Ketika pembahasan mengenai kekerasan terutama korbanya adalah perempuan, maka pembahasan akan menjadi sangat luas. Karena secara otomatis akan dibicarakan juga segi bentuk kekerasannya (kekerasan fisik, non fisik atau verbal dan kekerasan seksual), tempat kejadiannya (di dalam rumah tangga dan di tempat umum), jenisnya (perkosaan, penganiayaan, pembunuhan atau kombinasi dari ketiganya), maupun pelakunya (orangorang yang memiliki hubungan dekat atau orang asing).

Merujuk pada Rekomendasi Umum Nomor 19 Komite Penghapusan Diskriminasi Terhadap Perempuan (Komite CEDAW) tentang Kekerasan Terhadap Perempuan, menyatakan, "Kekerasan berbasis gender adalah suatu bentuk diskriminasi yang secara serius menghalangi perempuan untuk menikmati hak-hak dan kebebasannya atas dasar persamaan hak dengan laki-laki”. Kekerasan terhadap perempuan merupakan tindak penistaan dan pengebirian harkat dan martabat manusia, dapat terjadi di semua tingkat kehidupan, baik di tingkat pendidikan, ekonomi, budaya, agama, maupun suku bangsa.Hal ini karena pada dasarnya kekerasan terjadi akibat paham dunia yang masih didominasi oleh lakilaki.

Pada masa pandemic saat ini, kasus kekerasan terhadap perempuan di

${ }^{1}$ https://tirto.id/isi-pasal-28-uud-1945sebelum-dan-sesudah-amandemen-f8eH, diakses Tanggal 31 Januari 2021 
Indonesia meningkat 75 persen. Dalam siaran langsung lewat akun YouTube BNPB, Jumat (10/7/2020), dr Reisa Broto, tim komunikasi publik Gugus Tugas COVID-19, menayangkan presentasi dari Pusat Pelayanan Terpadu Pemberdayaan Perempuan dan Anak (P2TP2A) dan Komnas Perempuan. Dalam tayangan tersebut tercatat jumlah kasus kekerasan terhadap perempuan selama pandemik ada 14.719, yang dibagi ke dalam 3 kategori. Kasus di ranah personal 75,4 persen atau 11.105 kasus, ranah komunitas 24,4 persen atau 3.602 kasus, dan ranah negara 0,08 persen atau 12 kasus. Dari presentasi tersebut, diketahui bahwa kekerasan pada perempuan yang paling banyak terjadi adalah jenis kekerasan fisik, mencapai 5.548 kasus. Kekerasan psikis ada 2.123 kasus, dan kekerasan seksual 4.898 kasus.

Angka kekerasan di Banten, memang masih tergolong rendah, dan itu semua diperoleh karena adanya laporan, baik itu dari pihak korban maupun dari unsur masyarakat. Apabila ditelusuri secara mendalam ada kemungkinan angka itu akan terus bertambah. Berdasarkan catatan Lembaga Perlindungan Anak (LPA) Banten dalam semester I tahun 2020 pada Januari-Juni, tercatat 35 kasus yang melapor langsung ke LPA Banten. "Di antara kasus tersebut yang mendominasi adalah kejahatan seksual dengan persentase 95 persen. LPA Provinsi Banten menilai pandemik COVID-19 yang sampai saat ini belum juga berakhir, bahkan kurvanya terus mengalami kenaikan, telah membuat tingkat stres orangtua meningkat. Dalam kondisi seperti ini, anak-anak pun rawan mengalami tindakan kekerasan. Sementara itu kasus kejahatan seksual pada perempuan biasanya dimulai saat mereka saling berkenalan dengan orang asing di media sosial. "Dari jumlah kasus tersebut, pelaku tidak hanya kategori usia dewasa, namun ada juga yang kategori usia anak yaitu usianya di bawah 18 tahun.

\section{B. Usaha Pemerintah Daerah Dalam Pengentasan Diskriminasi Terhadap Perempuan. \\ Oleh karena itu untuk mempercepat} proses pengaduan kekerasan Dinas Pemberdayaan Perempuan Perlindungan Anak Kependudukan dan Keluarga Berencana Provinsi Banten (DP3AKKB) membuat aplikasi system informasi menangani pengaduan kekerasan (SIMANIS) yang merupakan aplikasi berbasis android yang dapat diakses masyarakat Banten atau oleh korban kekerasan $^{2}$.

Dalam proses laporan/pengaduan kekerasan terhadap perempuan dan anak yang berbasis IT ini pengaduan yang masuk akan segera direspons dengan cepat dan ditangani oleh unit Lembaga Layanan terkait antar lain Pusat Pelayanan Terpadu dan lembaga lainnya termasuk konseling dengan psikolog secara langsung. Namun terkadang upaya yang telah digagas pemerintah dilapangan tidak bisa berjalan dengan baik dan cendrung stagnan. Ini perlu adanya monitoring secara terus menerus oleh pihak pihak terkait. Dalam setiap laporan pertanggungjawaban negara dalam mekanisme internasional, yaitu bentuk laporan pertanggungjawaban pencapaian Sustainable Development Goals (SDGs). Berupa target untuk mengakhiri segala bentuk diskriminasi terhadap semua perempuan dan anak perempuan di mana saja, dan target dua, mengeliminasi segala bentuk kekerasan terhadap perempuan dan anak perempuan pada ruang publik dan privat, termasuk perdagangan (trafficking), kekerasan seksual, dan bentuk eksploitasi lainnya mengalami hal serupa, berjalan ditempat.

\section{Meningkatnya Korban Kekerasan Terhadap Perempuan}

${ }^{2}$ https://dp3akkb.bantenprov.go.id/. Diakses tanggal 31 Januari 2021 
Kekerasan seksual terhadap perempuan di Indonesia terus meningkat dan semakin kompleks. Dengan jumlah korban setiap tahun mencapai ratusan ribu orang. Data tersebut, bila dikaitkan dalam kurun waktu 12 tahun, meningkat sebanyak $792 \%$ atau hampir $800 \%$. Artinya kekerasan terhadap perempuan di Indonesia selama ini terus mengalami peningkatan hampir delapan kali lipat. Sejak tahun 2008-2018 kenaikannya terlihat konsisten, bahkan akhir tahun 2019 berdasarkan Catatan Tahunan (Catahu) Komnas Perempuan tahun 2019, angkanya naik enam persen. Angka itu merupakan fenomena gunung es. Indikatornya, setiap dua jam sekali ada perempuan mengalami kekerasan seksual di Indonesia. Dengan angka pelaporan kekerasan seksual terus bertambah dan semakin komplek.

Di sisi lain, permohonan perlindungan korban kasus kekerasan seksual yang dimintakan pada Lembaga Perlindungan Saksi dan Korban (LPSK), jumlahnya naik signifikan, dari 373 tahun 2019 menjadi 501 korban pada $2020^{3}$. Kasus-kasus di atas, merupakan kejadian nyata, adanya kekosongan hukum dan pentingnya perlindungan korban. Untuk Provinsi Banten permohonan perlindungan korban berbagai kasus yang dimintakan pada LPSK masih tergolong kecil, seperti data pada tahun 2018 hanya 83 permohonan. Rendahnya angka permohonan untuk Provinsi Banten memang angka kekerasannya masih tergolong kecil atau sebaliknya merupakan gambaran bahwa LPSK belum begitu dikenal oleh masyarakat dan aparat penegak hukum maupun instansi terkait lainnya. Selain itu kiprah LPSK di daerah untuk terlibat secara aktif pada kasuskasus yang menyita perhatian publik juga belum banyak diketahui oleh masyarakat.

\footnotetext{
${ }^{3}$ Harian Kompas, 9 Juli 2020.
}

\section{Kekerasan Terhadap Perempuan dalam Persfektif Islam}

Kaum perempuan dalam perspektif pemikiran agama Islam menjadi kajian yang cukup menarik, baik itu oleh para ilmuwan maupun oleh pemuka agama itu sendiri. Tema kekerasan terhadap perempuan ini bukan saja mengharuskan telaah yang bersifat keagamaan, tetapi juga perlu dikaji dengan suatu perbandingan yang bersifat komprehensif. Kecenderungan untuk membicarakan masalah ini, merupakan sebuah fenomena yang terus berkembang dalam masyarakat. Ini menandakan bahwa kekerasan terhadap kaum perempuan masih saja terjadi di abad melenia yang serba modern ini $^{4}$. Problematika yang dihadapipun senantiasa aktual dan dinamis karena situasi dan kondisi setiap keluarga yang satu dengan yang lain selalu berbeda. Problematika yang lahir dari kehidupan rumah tangga dewasa ini banyak yang menjurus kepada tindakan-tindakan kekerasan ${ }^{5}$.

$$
\text { Seiring dengan kemajuan }
$$
peradaban zaman, persoalan perempuan menjadi lembaran sejarah tersendiri yang patut untuk kita renungkan. Melihat kondisi perempuan yang masih menjadi obyek kekerasan dan perlakukan ketidakadilan dalam segala bidang, maka lahirlah beberapa tokoh perempuan yang menginginkan kemajuan dan perubahan akan nasib kaum perempuan tersebut dalam segala bidang, baik ekonomi,sosial, seni, budaya, pendidikan, hukum tidak terkecuali dalam bidang politik. Dalam perspektif agama Islam, perempuan bukanlah musuh atau lawan kaum lakilaki. Perempuan dalam pandangan Islam

\footnotetext{
${ }^{4}$ Muhammad Hasbi, Kekerasan Perempuan dalam Wacana Pemikiran Agama dan Sosiologi, Jurnal Pemikiran Islam Al-Tahrir, Vol.15, No,2 (2015)

${ }^{5}$ Bgd. M. Letter, Tuntutan Keluarga Muslim Dan Keluarga Berencana (Padang: Angkasa Raya, 1985), 7.
} 
merupakan bagian dari laki-laki demikian pula sebaliknya, keduanya bersifat saling melengkapi. Dalam surat ali-Imran ayat 195 di jelaskan "Tidak ada amal yang siasia diantara kamu, baik laki-laki maupunpe rempuan, karena perempuan bagian dari laki-laki, begitu pula sebaliknya". Perempuan dalam Islam tidak lagi menjadi seorang Kompetitor. Akan tetapi sudah menjadi kontributor bagi sebuah peradaban modern. .

Saat ini persoalan perempuan yang semakin mengemuka, sehingga banyak memunculkan tokoh-tokoh yang ingin memperjuangkan kemajuan dan persamaan hak bagi kaum perempuan. Para Tokoh perempuan tersebut berupaya meraih suatu kemajuan yang berarti bagi kaum perempuan, sekaligus melahirkan gerakan perempuan yang bersifat progresif. Sebut saja tokoh-tokoh seperti dalam berbagai literatur sejarah Islam, banyak sekali kaum perempuannya menekuni berbagai jenis profesi, mulai dari urusan politik atau pemerintahan, sampai kepada masalah kewanitaan. Sebut saja Ummu Salamah dan Aisyah (keduanya isteri Nabi), Shafiyah, Laila al-Ghiffariyah dan lainlainnya. Mereka bersama kaum laki-laki berlaga di medan perang. Begitu juga dengan Siti Khadijah binti Khuwailid (isteri pertama Nabi SAW.) dan Qillat Ummi Bani Ammar adalah contoh saudagar sukses pada masanya. Ada pula Zainab binti Jahsy yang bekerja sebagai penyamak kulit . Mereka-mereka adalah perempuan-perempuan hebat yang tergolong sukses dalam menjalankankan profesinya dan sekaligus sukses memerankan dirinya sebagai istri bagi suami mereka.

Tidak sampai disitu, di Indonesia juga pada masa sebelum kemerdekaan muncul nama-nama tokoh seperti sosok

\footnotetext{
${ }^{6}$ Turizal Husein, Etos Sang Kyai, (Yogyakarta : Tangan Emas, 2020), hlm.356
}

perempuan keturunan Kerajaan Aceh Laksamana Malahayati, Tjut Nyak Dien, Siti Walidah, Raden Ajeng Kartini, Hajjah Rangkayo Rasuna Said, Rahma El Yunisiah, Dewi sartika dan lain-lainnya. Munculnya para tokoh perempuan ini sebagai wujud cita-cita untuk mewujudkan kemajuan bagi kaum perempuan.

Perlindungan Terhadap Korban Kekerasan Dalam Perspektif Hukum Islam.

Dalam Islam, aspek hukum pidana menyangkut soal suatu perbuatan seseorang yang berdasarkan syariat dan telah ditetapkan (digariskan) sebagai suatu tindak pidana. Pembuat hukum, dalam hal ini adalah Allah SWT yang telah menggariskan berbagai jenis perbuatan (kejahatan) dikategorikan sebagai tindak pidana, seperti pencurian, penganiayaan, makar, pembunuhan dan perkosaan (kekerasan terhadap perempuan).

Fikih dalam bidang jinayah secara khusus mengatur pencegahan yang dilakukan oleh seseorang terhadap orang lain dan akan memberikan sanksi hukuman yang sesuai dengan tingkat kejahatan yang telah diperbuatnya, oleh karena itu tujuan dari ketentuan ini tidak lain diciptakan Allah untuk mendatangkan kemaslahatan umat. Sejalan dengan konsep tersebut Rasulullah SAW mengatakan, "Tidak boleh terjadi kerusakan kepada manusia dan tidak boleh manusia, dan manusia tidak diperkenankan membuat kerusakan atau kekerasan terhadap orang lain". Dan pelanggaran terhadap ketentuan hokum tersebut dikenakan hukuman berupa penderitaan badan atau harta ${ }^{7}$. Ini selaras dengan pendapat Roscoe Pound yang mengatakan, " law as a tool of social engineering", hukum itu sebagai alat untuk mengubah masyarakat. Efek jera memang

${ }^{7}$ Makhrus Munajat, Dekonstruksi Hukum Pidana Islam (Yogyakarta: Logung Pustaka, 2007), 2. 
harus dilakukan, jika ini diabaikan, maka besar kemungkinan setiap pelanggaran akan menjadi habit perilaku kejahatan.

Dalam konteks hukum Islam, tujuan ditegakkan hukum Islam menurut para ulama yaitu, mendidik jiwa, mensucikan manusia, menegakkan keadilan, merealisir kemaslahatan, dan kebahagiaan di dunia dan di akhirat ${ }^{8}$. Upaya ini dilakukan untuk menciptakan kemaslahatan umat dan sekaligus menegakkan keadilan. Agama Islam sangat memegang teguh prinsip keadilan. Hukum berlaku sama dengan tidak melihat kedudukan dan status seseorang.

Perlindungan Islam Terhadap Perempuan

Agama Islam sejak diturunkan memiliki pesan fundamental, yakni mengusung kedamaian dan keadilan. Nilainilai Islam Allah ajarkan kepada makhluk ciptaaan-Nya merupakan bentuk manifestasi pesan Illahi untuk menebar kedamaian di seluruh alam. Agama Islam yang diajarkan para Nabi secara tegas menolak segala bentuk macam kekerasan,termasuk kekerasan terhadap perempuan. Islam sebagaimana agama lain mengajarkan kepada pemeluknya untuk tidak berbuat kasar dan kejam kepada perempuan. Bahkan dalam Islam pertanda kesempurnaan iman seseorang diwarnai dengan kebaikan budinya kepada perempuan. Allah SWT di dalam Al-Quran dalam surat Ar-Rum ayat 21 mengajarkan secara rinci hubungan laki-laki dan perempuan agar membangun relasi secara harmonis. Hubungan yang membawa saling menyayangi dan merasa tentram. Jika dapat terus dijaga dan dipelihara, besar kemungkinan tidak ada lagi muncul bentuk-bentuk kekersan terhadap perempuan. Dalam pandang Islam dikatakan manusia yang baik, adalah yang berlaku dan berbuat baik terhadap istri dan

\footnotetext{
${ }^{8}$ Abdussalam Arief,'Filsafat Hukum Islam". 28 November 2011
}

anak-anak perempuannya. Atas dasar inilah maka setiap asumsi yang menyatakan bahwa Islam merendahkan atau melecehkan perempuan adalah salah besar. Karena sifat merendahkan, melecehkan, atau mencederai apalagi menindas manusia merupakan pelanggaran terhadap hak-hak Allah SWT, karena Allah SWT segala macambentuk kekerasan termasuk terhadap perempuan. Sebagaimana ditegaskan bahwa sesama orang-orang beriman dilarang untuk saling menyakiti. Agama Islam secara penuh memberikan perlindungan terhadap perempuan dan menolak secara tegas praktik-praktik kekerasan.

Dengan memperhatikan sejumlah prinsip yang digariskan Islam dalam kehidupan rumah tangga, sangat jelas bahwa segala macam bentuk perilaku kekerasan terhadap perempuan, sangat bertentangan dengan prinsip-prinsip dasar hukum dalam agama Islam. Pihak laki-laki (suami) yang melakukan tindak kekerasan, akan mendapatkan hukuman sebagai orang-orang yang berdosa besar karena melanggar prinsip-prinsip dasar agama. Tidak hanya mendapatkan sanksi moral, melainkan juga dapat dijerat hukum pidana. Terlebih dalam konteks Indonesia, lahirnya UU No. 23 Tahun 2004 tentang penghapusan kekerasan dalam rumah tangga, merupakan landasan hukum kuat untuk mewujudkan pencegahan sekaligus penghapusan tindak kekerasan, disamping perlindungan korban serta penindakan terhadap pelaku kekerasan ${ }^{9}$.

Lahirnya UU No. 23 Tahun 2004 membawa angin segar sekaligus sebagai bentuk perlindungan hukum terhadap perempuan. Ada 5 point yang dapat di

\footnotetext{
${ }^{9}$ Bustanul Arifin. Lukman Santoso.
}

Perlindungan Perempuan Korban Kekerasan Dalam Rumah Tangga Perspektif Hukum Islam. De-Jure. Jurnal Hukum dan Syariah Vol. 8, No. 2, h. 113125, (2016) 
adopsi. Pertama, penghapusan kekerasan dalam rumah tangga dilaksanakan berdasarkan asas penghormatan hak asasi manusia, keadilan dan kesetaraan gender, non diskriminasi dan perlindungan korban. Kedua, tujuan dari penghapusan kekerasan dalam rumah tangga adalah untuk mencegah segala bentuk kekerasan dalam rumah tangga, melindungi korban, menindak pelaku kekerasan dalam rumah tangga dan memelihara keutuhan rumah tangga yang harmonis dan sejahtera, maka tindak pidana kekerasan dalam rumah tangga pada umumnya merupakan delik umum, namun ada pula yang bersifat delik aduan, yaitu tindak pidana kekerasan fisik psikis ringan serta pemaksaan hubungan seksual yang dilakukan suami terhadap istri atau sebaliknya. Ketiga, undang undang penghapusan kekerasan dalam rumah tangga menetapkan bentuk-bentuk kekerasan dalam lingkup rumah tangga yaitu kekerasan fisik, kekerasan psikis, kekerasan seksual, yang penjatuhan hukumannya berbeda dengan ketentuan yang telah diatur dalam pasal 351 KUHP. Keempat, penelantaran rumah tangga yang mempunyai arti bahwa setiap orang dilarang untuk menelantarkan orang dalam lingkup rumah tangganya, padahal menurut hukum yang berlaku baginya atau karena persetujuan atau perjanjian ia wajib memberikan kehidupan, perawatan, atau pemeliharaan kepada orang tersebut. Kelima, pemerintah dan masyarakat berkewajiban dalam upaya pencegah terjadinya kekerasan dalam rumah $\operatorname{tangga}{ }^{10}$.

Kekerasan dalam rumah tangga dan rata-rata yang menjadi korban kekerasan adalah kaum wanita memang menjadi realitas dan terus mengalami peningkatan. Banyak faktor yang menjadi penyebab

${ }^{10}$ Undang-Undang Nomor 23 Tahun 2004 tentang Penghapusan Kekerasan dalam Rumah Tangga utama terjadinya tindakan kekerasan ini. Salah satunya adalah kondisi dari budaya yang terdiri dari berbagai macam suku dan hukum adatnya dan sistem hukum Negara sendiri yang kurang responsif dalam melindungi kepentingan perempuan. Upaya dari pemerintah untuk memberikan perlindungan bagi perempuan harus terus dikampanyekan, untuk meminimalisir tingginya angka kekerasan terhadap perempuan. Oleh karena itu sebagai bentuk pencegahan dan meminimalisir semakin tingginya angka kekerasan terhadap perempuan pemerintah selaku pemegang kekuasan tertinggi berkewajiban melindungi korban, dan menindak pelaku kekerasan dalam rumah tangga. Pemerintah dan masyarakat wajib melaksanakan pencegahan, perlindungan, dan penindakan pelaku sesuai dengan ajaran Islam yang luhur, falsafah Pancasila serta UUD 1945. Terlebih negara berpandangan bahwa segala bentuk kekerasan, terutama kekerasan dalam rumah tangga, adalah pelanggaran hak asasi manusia dan kejahatan terhadap martabat kemanusiaan serta bentuk diskriminasi. Selain itu, sebagai upaya perlindungan terhadap perempuan, perlu segera diwujudkan Pengadilan Khusus yang menyangkut kekerasan terhadap perempuan dan kekerasan dalam rumah tangga. Hal ini sebagai upaya menjawab kompleksitas permasalahan terkait kekerasan dalam rumah tangga. Dengan adanya pengadilan khusus ini, korban kekerasan dalam rumah tangga khususnya perempuan akan mendapatkan perlindungan hukum yang berkeadilan.

\section{E. Penutup}

Membangun dan memajukan Banten tidak cukup hanya pembangunan fisik saja. Namun perlu dibarengi dengan membangun kualitas Sumber Daya Manusia (SDM). Perlu kreatifitas dan inovasi serta kemampuan manajerial 
pemimpinannya untuk dapat membrainding sekitar 12 juta jiwa penduduknya yang serba terbatas kemampuan akademiknya. Mensejahterakan dan mengurangi angka tindak kekerasan terutama bagi kaum perempuan adalah salah satu kuncinya. Islam sejak ditransformasikan di muka bumi memiliki pesan damai. Dan sangat sesuai dengan Motto Banten yang Islami. Berdasarkan tulisan ini dapat disimpulkan bahwa Islam memberikan perlindungan terhadap perempuan dalam banyak aspek. Dengan demikian, sangat tragis jika teksteks normative dalam Islam dipahami sebagaimana adanya atau secara tekstual semata, sehingga agama Islam memiliki kesan tidak manusiawi dan tidak berpihak terhadap kaum perempuan.

Banten di usia ke 20 tahun, harus segera berbenah dari status pasien pesakitan menuju pasien yang terbebas dari berbagai macam penyakit-penyakit kemiskinan, kebodohan, keterbelakangan dan rendahnya Indeks Pembangunan Manusianya (IPM). Semua ini diperlukan adanya berbagai macam kreatifitas, inovasi dan berbagai macam strategi yang tepat guna memperbaiki manajemen disetiap lembaga dan sekaligus memangkas berbagai macam birokrasi yang terkadang mempersulit pelayanan kepada masyarakat. Untuk sebuah perubahan kearah yang lebih baik dibutuhkan sebuah keberanian, dan itu harus segera dimulai. Tidak hanya manusia saja yang sulit untuk memulai. Mesin listrikpunpun sangat berat untuk memulai pekerjaan. Dia harus menaikkan arus listrik sampai dua kali lipat arus normalnya, sehingga untuk memulai ia memerlukan peralatan bantu untuk memperkecil rintangan. Motor listrik mempunyai variable malas, demikian juga kita, manusia. Malas bukan variable yang tidak bisa diperbaiki. Manusia punya kontroler hati yang bisa memperbaikinya. SDM yang baik dan bisa diandalkan ketika ia memiliki kontrol hati dalam menjalan setiap amanah yang dipikulnya.

Banten sebagai pintu gerbang Jawa dan Sumatera memiliki sejuta peluang. Setiap hari Banten akan bertemua dengan peluang, karena Banten banyak menyimpan kekayaan yang belum dikelola secara maksimal. Peluang yang begitu besar di depan mata akan hilang begitu saja tanpa di awali dengan memulai secara cepat, tepat dan benar. Petinju yang jatuh $\mathrm{KO}$, pesilat yang menyerah baru di Babak awal, karena belum siap untuk memulai. Berbagai proyek yang gagal dan terbengkalai serta berantakan karena lengah dalam memulai. Pemerintah selama ini cendrung acuh dan tidak pernah membaca ulang masukan dari berbagai macam unsur dan elemen masyarakat , sehingga Banten selalu tertinggal dalam dalam segala hal dengan provinsi lainnya. Memulai untuk perubahan adalah pekerjaan awal setelah berdoa. Menjadikan Banten dengan semboyan "IMAN TAQWA" sebagai landasan pembangunan menuju Banten Mandiri, Maju dan Sejahtera "Darussalam". Tidak akan terwujud tanpa doa para pemimpin dan rakyatnya. Berdoa wajib dilakukan untuk memanen sebuah kesuksesan. Tidak ada kesuksesan tanpa memulai. Dan memulai tidak akan berjalan sempurna jika kita melupakan DIA sang pemberi Kesuksesan itu sendiri.

\section{DAFTAR PUSTAKA.}

Abdussalam Arief,"Filsafat Hukum Islam". 28 November 2011 Bustanul Arifin. Lukman Santoso. Perlindungan Perempuan Korban Kekerasan Dalam Rumah Tangga Perspektif Hukum Islam. De-Jure. Jurnal Hukum dan Syariah Vol. 8, No. 2, h. 113-125, (2016)

Muhammad Hasbi, Kekerasan Perempuan dalam Wacana Pemikiran Agama dan Sosiologi, Jurnal Pemikiran 
Islam Al-Tahrir, Vol.15, No,2 (2015)

Bgd. M. Letter, Tuntutan Keluarga Muslim Dan Keluarga Berencana (Padang: Angkasa Raya, 1985), 7.

https://tirto.id/isi-pasal-28-uud-1945sebelum-dan-sesudah-amandemenf8eH.

https://dp3akkb.bantenprov.go.id/.Harian Kompas, 9 Juli 2020

Turizal Husein, Etos Sang Kyai, (Yogyakarta : Tangan Emas, 2020), hlm.356
Makhrus Munajat, Dekonstruksi Hukum Pidana Islam (Yogyakarta: Logung Pustaka, 2007), 2.

Undang-Undang Nomor 23 Tahun 2004 tentang Penghapusan Kekerasan dalam Rumah Tangga. 
Banten Dan Angka Kekerasan Terhadap Perempuan Persfektif Agama Islam

Rausyan Fikr. Vol. 16 No. 1 Maret 2020. ISSN. 1979-0074 e-ISSN. $9772580594187 \mid 80$ 